\title{
Using Educational Platform Edmodo for Developing Some Writing skills of the Third-Year Prep Students
}

\author{
Hend Gamal Mahmoud Abdel-Rhaim ${ }^{1}$, Abdullah Mahmoud Ismail ${ }^{2}$, Muhammad Reyad Omar ${ }^{3}$ \\ ${ }^{2}$ Professor of Curricula \& EFL Methodology, Faculty of Education, Sohag University, Sohag, Egypt. \\ ${ }^{3}$ Lecturer of Curricula and instruction, Faculty of Education, Assiut University, Assiut, Egypt.
}

DOI:

\begin{abstract}
This study aimed at investigating the effectiveness of using Edmodo as a teaching and learning platform to develop writing skills for third-year prep-stage students for governmental language school. The researcher followed the quasi-experimental approach, so she chose a random sample of 44 EFL students at Bardis governmental language school in the directorate of Sohag. The participants were divided into two groups. The control group of (22) students, the experimental group of (22) students. The two groups were equivalent in terms of their age, previous learning, and achievement in the English language in general, achievement in writing in particular. The researcher used a tool. The tool was a writing test to measure students' writing skills after the administration. The educational platform Edmodo was used as a teaching and learning virtual class for explaining the writing lessons included in the course of the thirdyear prep-stage. The findings of the study revealed that there was a statistically significant difference between the mean scores achieved by the experimental group and the control group in the postassessment of student's writing performance in favor of the experimental group. This showed a remarkable improvement in writing skills for the experimental group as compared with the control group.
\end{abstract}

Key words: Educational platform Edmodo, Writing Skill.

\section{Introduction}

Language is an interaction device. People use the language to obtain expression or to create it. People should express their emotions, feelings, and ideas. Language is not only a means of communication but also a means of representing human intelligence. In order to provide some tangible evidence to the students who are creating progress in the language, this may satisfy a psychological need.
Writing has offered a range of tasks in the classroom and can develop language communication through work that can be made available out of class.

It is important to pay close attention to writing skills, to deal with writing problems for language learners, and to suggest strategies to help language learners develop writing skills in a foreign language, as well as the best way to teach 
writing tasks. For instance, the school is considered a factory that produces outstanding writers, so the most suitable place to teach students how to produce a creative piece of writing. This is emphasized by Keneth (2010, p.1) who says that good writers are not born. Msanjlla (2005, p.5) reported some writing problems and errors committed by students, such as capitalization problems, punctuation problems, poor organization, spelling, and grammatical errors.

Edmodo was created by Nic Brog and Jeffo Hara (2008), who realized the need to improve the school atmosphere to fulfill the connectivity of the World of the $21^{\text {st }}$ Century. Edmodo is a safe and free advertising environment; games and other distractions can affect students. Students use Edmodo to contact their teachers to inquire questions about lessons and homework and work with their classmates on activities and ideas for the project. Through using Edmodo, students and teachers can reach out to one another by sharing ideas, problems, and helpful tips. A teacher can assign and grade work on Edmodo; students can get help from the entire class on Edmodo (Mills

\section{\& Chandra 2011).}

As a teaching and learning tool, studies have also been conducted to investigate the use and the effectiveness of Edmodo. Enriquez (2014) found that Edmodo's collaboration enables students to enhance the efficiency of their online jobs. Dowling (2011) finds Edmodo permitting students and teachers to engage in the learning process to discuss the specific course. Monalsia and Adri (2013) claimed parents should be able to take part in learning their kids and how to use the platform as they can checking the development and progress of mobile technology for their children, Al-okaily (2013) investigated that Edmodo's use of mobile devices could encourage students to collaborate on an intensive English Program.

It can be concluded that educational platform Edmodo fits the present approach to learning and answers the question as to how learners connect the information in the digital age; however, educators must ensure this educational platform Edmodo properly integrated into every facet of education rather than its current uses in higher education in the form of open courseware to promote the $21^{\text {st }}$ Century. Hence, learners become motivated learners, problem solvers, and critical thinkers. Previously, students had problems with their writing skills

\section{Background of the Study}

Writing is considered an essential skill for anyone to organize the reality of the world. Learners have faced a lot of writing skills problems, especially in writing a paragraph, and some sub-skills. Spelkovab \& Nicolas (n.d) believes that writing is linked to many ways of speaking, but it is also considered much more complicated, possibly because of the attitudes to the meaning of written texts and principles correlated with correctness and the seriousness of mistakes. Indeed, being aware of their possible errors and a poor level of writing skills, learners also do not want to be 
given writing assignments, as they view the assignment as likely to cause anxiety. This is one of the reasons why many learners are worried about their writings in another language and consider writings to be one of the most difficult for learning. Therefore, it is essential to assign the importance of the writing skill, writing problems faced by the language learners, as well as the appropriate way for teaching writing activity to propose solutions to help language learners to master writing skill in the foreign language.

Through the experience of the researcher as a teacher in the preparatory schools, the researcher found that there is an obvious weakness in the writing skills with pupils to recognize the different types of writing. This refers to the inability to achieve the educational goals of the preparatory stage through the English curriculum. Since face-to-face training might not be effective enough due to lack of time, a flexible improvement in training was needed. Edmodo has been active in solving the time shortage problem. Through using Edmodo, a teacher could pursue modern methodologies and keep pace with new research in the field of EFL teaching. It is observed that students' level in writing skills generally is remarkably low according to some previous studies.

There are many recent studies conducted about using Edmodo such as Anbe's (2013), Shockley's (2013), Gushiken's (2013), Cole's (2012), Thongmak's (2013).
Reciprocal teaching strategies were used, and student initiative was encouraged, supporting the role of the teacher as a mediator or moderator, rather than the source of knowledge. Student participation, student engagement, the complexity of discussion, and the effectiveness of Edmodo discussion boards as a tool are discussed. The researcher performed a pilot study on third-year prep stage students in which a writing test was administered.

The result of this test pointed to $85 \%$ of their writing skills problems. It emphasized that the writing skills of students indicate some problems of writing. In addition, to answer this question, the researcher interviewed English teachers (what are the problems of writing skills for the thirdyear prep stage?). According to this interview, in the students' writing, the researcher found several problems such as punctuation, grammar, the relevance of ideas, punctuation, the use of appropriate vocabulary, and the improper use of prepositions through different types of writings such as writing an e-mail, paragraph, letter, postcard and taking a note. The result of this interview was that $85 \%$ of the students had problems with their writing skills. And the results of this interview highlighted the result of the writing skill test. So, the results of this interview and the writing skill test are outlined in this table. The analysis of the calculated students' errors with their percentages can be listed in this table as follows: 
Table (1) The percentage of the weakness at writing skills

\begin{tabular}{|c|c|c|}
\hline Skill & Percentage & Description \\
\hline Quality of contents & $66 \%$ & $\begin{array}{l}\text { Students did not use clear and obvious and did not focus } \\
\text { on the relevance of ideas. }\end{array}$ \\
\hline Organization of Ideas & $35 \%$ & Students did not organize their ideas. \\
\hline Grammar & $74.5 \%$ & Students committed grammar errors. \\
\hline Cohesion & $26 \%$ & Students did not write in a more logical and unified. \\
\hline Conventions & $36.66 \%$ & Students committed errors in punctuation and spelling. \\
\hline Word Choice & $25 \%$ & Students cannot use clear and precious words. \\
\hline
\end{tabular}

Data presented above revealed that $66 \%$ of students were weak in the quality of contents. $35 \%$ of students were weak in the organization of ideas. $74.5 \%$ of students were weak in grammar. $26 \%$ of students were weak in cohesion. $36.66 \%$ of students were weak in conventions. $25 \%$ of students were weak in word choice.

\section{Statement of the Problem}

It is clear from the previous introduction, Pilot assessment, and observations of the researcher as a language teacher, that preparatory school students have poor writing performance. The current study tried to handle these problems by developing a program based on using Edmodo.

\section{Objectives of the Study}

This study aimed at:

Developing writing skills for preparatory stage students.

\section{Questions of the Study}

This study attempted to answer the following question:

What's the effect of a suggested connectivism based- program through using educational platform Edmodo on developing third-year prep students' writing skills?

\section{Hypotheses of the Study}

The researcher tested the following hypothesis:

There would be a statistically significant difference at $\geq(0.05)$ between the mean scores of the experimental group and that of their control peers in the post-assessment of their writing performance.

\section{Delimitations of the study}

This study was delimited to the following delimitations:

1. The sample of the study was delimitated to a control group and an experimental group, 22 students in each group at Bardis Governmental language school prep school where the researcher worked and because it had the technological possibilities, electronic laboratory and necessary needs. The school at the administration of El-Ballina. The group was from 3 girls and 18 boys.

2. A list of writing rubrics based mainly on writing mechanisms. The mechanisms are 
based on its integration and affective dimensions of writing. Some writing skills (letter- e-mail- paragraph- note- essaypostcard) for writing mechanisms. The researcher chosen these writing skills because the students had problems and weakness. Also, these skills are chosen because they are suitable for third-year prep students.

3. Aim High 3 as an advanced level for governmental language schools set by Jane Hudson at oxford university press as the literary material of the program. It is meant to be simple to make it easier for the students.

4. The study was delimitated to third-year prep school students. The third-year prep stage has been chosen, because it is the transition period between the preparatory stage and the secondary stage. In preparatory stage, students are asked to write in a good manner, but they need to focus on using the mechanisms of writing. In secondary stage, they are asked to write in a fluent way.

\section{Significance of the Study}

The significance of the study stemmed from the following considerations.

\section{Theoretical significance}

- To keep up with the recent global trends in education development and increase the effectiveness of the educational process.

- To present a model for an educational program based on connectivism through educational platforms.
- To Provide good and new methods of communication among teachers and students.

\section{Applied significance}

This study would be highly significant for:

\section{Teachers}

The study can draw the attention of English language teachers to the value of integrating Edmodo technology as a means of improving writing skills, which can lead to improve writing skills and improve skills for learners in general and eliminate conventional methods and promote the use of new non-traditional methods.

\section{Decision-makers}

The study may help concerned decision-makers to employ the Edmodo technology in teaching the English language and other teaching fields.

\section{School principals}

They may be influenced by the necessity of providing school laboratories with internet and electronic equipment which help teachers employ modern technology in teaching English and other subjects.

\section{Supervisors}

This study stimulates specialists' and supervisors' interest to conduct training courses for teachers to enhance their skills in using the Edmodo approach in teaching English writing skills and other subjects.

\section{Students}

It may encourage and motivate students to use Edmodo to earn knowledge. 


\section{Researchers}

Guiding researchers in identifying new tools for evaluating teaching. Directing other researchers' attention to the area reflection considering it in further studies.

\section{Review of Literature}

\section{Edmodo as an Educational Social Networking}

\section{Platform}

The concept of a social network that arises from Web 2.0 is that people are connected to one or more social connections, thereby creating social communications for people (Donmus 2010). Several social networking tools, such as Facebook and Twitter, are developed with microblogging software that enables private users to post comments, event descriptions, graphics, or images, and blogs may leave comments or messages on blogs (Looi and Yusop 2011).

Arroyo (2011) describes Edmodo as a superb knowledge-building communication tool enabled by social networking and collaboration, providing learners and educators with a safer learning platform. Evans and Kilinc (2013) found that Edmodo provides teachers with an interrelated toolkit for managing the classroom during their time in the classroom. Thibaut (2015) also states that Edmodo allows teachers outside the classroom to perform class-related duties. Furthermore, in their study or through their work, some researchers and educators provide constructive feedback on Edmodo.

Edmodo is able to communicate, exchange and discuss the text, images, audio, and video with teachers and students. Students can learn individually by taking quizzes, completing tasks, participating in discussion groups, reviewing grades, receiving input from teachers and peers, exchanging ideas and collaborating, etc. Teachers for particular groups of students create Edmodo classes; teachers may also create smaller groups within all groups, enabling them to provide differentiated individual or group-based instruction. Teachers have set up the community and share the group code. Students will sign in at Edmodo using the group code without entering their email addresses and other personal details. This will confirm the protection of this website, whether for younger students or adults, regarding any complaints concerning the publishing of personal information on the website (Hourdequin 2014).

In addition, Wallace (2014) describes that there has been a trend in social networking sites that have developed online social environments where students and teachers can also participate as instruments to facilitate distance learning in online communication. Wallace adds that social networking sites can help to increase the level of attendance and involvement in learning activities when incorporated into effective classroom models. This is often due to the fact that most social networking platforms allow users to build and exchange digital resources, making it easier for teachers to gather and share multimedia resources to facilitate learning for students and provide learners with a conference. 
In conclusion, the use of web-based social learning applications has an important role to play in improving language skills, learner motivation, improving learning performance, encouraging positive change in learning roles, improving writing skills and motivation.

\section{Edmodo in Teaching Writing Process}

An essential characteristic of the current application is the establishment of student cooperation within the network-learning environment. For specific types of writing tasks, Edmodo is suggested to empower learners to communicate as an advantageous tool, this form of personal contact with literary texts facilitates dialog and feedback from students as well as teachers. In writing instructions, Edmodo is believed to be helpful.

With regard to teaching writing skills, Lara (2013) argued that by continuing lessons by receiving technology, Edmodo could maximize learning time in the classroom as students could access it wherever and whenever they wanted. Though students and teachers are in their homes, the training process could still take place. Alfian (2013) also stated that students use Edmodo to participate in collective learning activities in which writing processes such as planning, writing, editing, and publishing were carried out. In the planning stage, the students are interested in selecting the topic they are going to write about. Students were asked to use brainstorming to write a draft in the drafting process to assist them in a good series. In the meantime, learners are asked to work in the editing process in a group and share their written drafts to be verified by group members. Finally, students during the publication process are required to post their writing on Edmodo.

The pre-writing phase of the writing process involves arranging and organizing concepts. The instructor also initiates preparation by encouraging learners to brainstorm ideas, clustering terms related to the writing subject, and other strategies (Seow 2002). At this point, using Edmodo provides a variety of options for a teacher to help students begin to think. For instance, to believe or post specific pictures of students writing topics to discuss them, the teacher can post discussion questions for school students. Edmodo is an efficient tool for learner engagement, varied comprehension, and use of the target language (Hariri \& Bahanshal 2015). Students write and edit their work in the second phase of process learning, using their prior vocabulary and structuring skills. With the minimal language comprehension of students, they fail to bring their ideas together. Instead of minor mistakes, cutting, pasting, and automatic spelling correction help students to focus on critical writing problems. By opening Google Docs to join Edmodo, students can write and edit their writings (Kongchan 2015). Teachers who have Edmodo as a virtual class may compel their students to spell correctly in terms and correctly use punctuations in their discussions. Students are therefore used to spell the whole words such as 'you' instead of 'u' and 'I' instead of 'i.' In addition, 
students' use of Edmodo increases their enhancement in precise structures of writing.

Teachers who use the usual method of collecting student writings, reviewing papers, and writing feedback, before they get their notes back, it takes time for students to forget the subject. The immediate online feedback from Edmodo enables students to make improvements to their suggestions while the topic remains fresh in their minds (Carolan \& Kyppö 2015). Extended teacher time is also saved by using a form of automatic feedback generator for and student's draft, giving them more feedback on other student writing functions (Ware \& Warschauer 2006).

At the same time, the use of a web-based instrument such as Edmodo, which promotes contact between students and teachers, provides a wealth of peer input and teacher feedback. In addition, students will have more chances to use Edmodo to rewrite their writings than in the typical way in which students would compose one or two drafts for each piece at most. Moreover, Edmodo enables teachers to use such features when offering feedback for students, such as using different colors to comment and highlight texts. In line with a report on the efficacy of the use of Edmodo in writing teaching, Shams-Abadi et al., (2015) concluded that as "a result of using these characteristics, students who obtained feedback via Edmodo were more conscious of their errors in writing" (p. 95).

Therefore, there is no doubt as to how Edmodo can make it easier for students to need a place to learn. Maazi and Janfeshan (2018) analyzed
Edmodo's effect on Iranian learners' writing skills and attitudes, finding that Edmodo has significantly improved learning abilities related to English as a foreign language. Teachers also indicated that students had optimistic attitudes regarding the classroom's use of Edmodo. In writing instruction, Edmodo assumed to be applicable. In writing instruction, Edmodo assumed to be applicable. Some researches have shown how Edmodo operates in writing classes (Adas \& Bakir 2013; Gardner 2013; Pop 2013; Karyawati 2014; Abadi, Ahmadi \& Mehrdad 2015) through the GBA (Genre Based Approach) adaptation, as confirmed by Lara (2013).

\section{Method}

\section{Participants of the Study}

Participants in the present study were third-year prep stage. Two classes were randomly chosen from one of Sohag Governmental Language Schools, namely Bardis Governmental Language school in the year 2019-2020 The sample of the study consisted of (44) students distributed into two groups. Then, they were randomly assigned to two groups, experimental (N: 22) and control (N: 22) students who were chosen randomly.

To make sure that the development of the students' writing skills is attributed only to the effect of teaching through Educational Platform Edmodo. The researcher attempted to control some variables. These variables are:

- Age: all students' ages ranged from 15-16 years old. 
- Grade: all the students were in the third-year prep stage at a governmental language school.

- Gender: the availability of boys more than girls, the number of girls is three. Boys and girls were chosen to get involved in the experiment because they illustrated the readiness to participate, and it was easy to communicate with them at any time.

- Place: they all live at Bardis in Sohag Governorate with the similar socio-cultural background.

\section{Design of the Study}

The present study followed the quasiexperimental design. Two complete classes were randomly assigned into two an experimental group or a control group. The experimental group students received instruction through using the educational platform Edmodo for developing their EFL writing performance and motivation. The control group received traditional or regular instruction. By the conclusion of the instructional intervention, students in both groups were posttested for their writing performance.

\section{The Suggested Program}

This program was connectivism based program through using the educational platform Edmodo in which students were exposed to learnercentered activities where they are encouraged to construct their knowledge and control their learning with the help and guidance of their teacher. It was be designed to provide them with a variety of opportunities to develop their writing skills and to motivate them towards learning
English. Each lesson was divided into three steps: pre-writing stage (included presentation and modeling), while writing stage (included group work, individual practice, and feedback), and post-writing stage (included the lesson evaluation and varied questions).

\section{Designing the program}

To build up the program, the researcher followed the procedures below:

\section{a) Preparing an EFL Writing Rubrics}

To identify the EFL writing rubrics needed to be acquired by third-year prep students, a rubric was designed and submitted to the jury of faculty members. They determined the most necessary items for third-year students.

\section{b) Selecting the topics of writing skill}

The topic of the writing of each type of writing was selected from the student book issued by the Ministry of Education for the third-year prep stage. The six types were modified and adapted to suit the learners.

\section{c) Building a Framework for the Program}

Having the writing rubrics defined, a framework for the Program was designed including the general objectives, learning objectives, content, procedures, Learning Resources, Teaching \& Learning Activities, and Evaluation Techniques.

\section{d) Validity of the Program}

To establish the validity of the program, it was presented to a group of jury members who were asked to evaluate:

1. The pertinence of the behavioral objectives of every unit to the general aims of the program. 
2. The suitability of topics and content areas to the program objectives and aims. 3. The appropriateness of the activities, exercises, and evaluation means to achieve the objectives.

3. The clarity of the instruction.

4. After following the directions of the jury, the program was developed, and relevant changes were made in the light of the jury's view.

\section{Piloting of the Program}

Objectives of Piloting the Program

The pilot study of the program attempted to determine:

The suitability of the timing of the various activities and exercises of every session in every type as well as a program as a whole/The applicability of the activities and exercises for online learning. The suitability of the program content for the third-year prep students/The clarity of the instructions that included the program/Technical problems and difficulties that may arise when using the website and solutions that can be suggested to solve them.

The jury members found the program as a whole well-prepared and suitable for the purpose it was designed for. The program was applied to a random sample of (12) students from El-Ballina Governmental Language School, who had the same characteristics as the study sample. To achieve these objectives, six lessons was administrated to a randomly chosen third-year prep-stage (12 students). These lessons were:

1. Unit 1: lesson 1: Write a letter to an exchange friend.
2. Unit 2: lesson 1: Write a note using conjunctions

3. Unit 3: lesson 1: Write a paragraph about your favourite football player

4. Unit 4: lesson 1: Write an e-mail to apologize for getting angry about something unimportant.

5. Unit 5: lesson 1: Write a postcard to your friend about your holiday

6. Unit 6: lesson 1: Write an Essay about future.

The pilot study lasted for two weeks starting on Thursday $10^{\text {th }}$ October 2019 and ending on Thursday $24^{\text {th }}$ October 2019. In the end, the program and its content were suitable for the students and their levels. This step enables the researcher to ensure that the program was valid for the implementation.

During the introductory session at school, the researcher told the students the instructions for using the educational platform Edmodo and gave them the usernames and passwords. Every type of writing has one session a day. When students logged into the platform Edmodo, they had to inform their teacher and to keep communicating with him online. Every session has three stages of pre-writing activities (warm up-modeling), writing activities (group work-individual practice), post writing activities (Edmodo feedback(rewriting), evaluation). Using the discussion group and individual practice the student's comments and give their opinions. At the end of every session, students gave their opinions. 


\section{Evaluating the Pilot study of the Program}

One of the measurements approaches able to provide critical information about the program as a process is formative evaluation. It is conducted during the development or delivery of a program to make adjustments on the fly for improvement. It is based on the observations of the researcher as well as the feedback received from students. Using this type of evaluation, the following modifications were made in the final form of the program:

1. Based on the students' feedback, the instructions for using the educational platform Edmodo were not clear enough so the researcher added some print screens of the website.

2. Students'faced some problems as they have forgotten their passwords, but the researcher has all their usernames and passwords.
3. Students communicated with teachers via WhatsUp instead of the educational platform Edmodo.

4. Students send their answers via WhatsUp instead of the educational platform Edmodo.

5. Some students use the educational platform Edmodo as a tool for fun and luxury.

Another type of evaluation that primarily aims to get the total picture of the quality and the effectiveness of the produced program is summative in its nature. For that purpose, an evaluation sheet was constructed and validated by a jury of faculty members. The pilot study evaluation sheet was then submitted to the students to get their opinions about the skills they studied during the pilot study. It was translated into Arabic to be easy for the students to understand. Students' answers were scored and tabulated as showing in the following table (3):

Table (2) The Summative Results of Piloting the program

\begin{tabular}{lllll}
\hline \multicolumn{1}{c}{ Statement } & Agree & Not sure & Disagree & Ratio of \\
\hline 1.The program helped me to improve my ability to write & 11 & 1 & - & $95 \%$ \\
2.The program content was relevant to my interests. & 10 & 1 & 1 & $90 \%$ \\
3.The program content was appropriate for my needs. & 10 & 1 & 1 & $90 \%$ \\
4.The program content was compatible with my level. & 12 & - & - & $100 \%$ \\
5. The way of teaching the program was interesting. & 11 & - & 1 & $95 \%$ \\
6.The time allocated for the program was enough. & 9 & 1 & 2 & $85 \%$ \\
7.The activities and exercises were various. & 12 & - & - & $100 \%$ \\
8.The instructions of the program were clear. & 10 & 1 & 1 & $90 \%$ \\
9.The videos were suitable. & 12 & - & - & $100 \%$ \\
10.The time I spent in the research of the program was fruitful. & 12 & - & - & $100 \%$ \\
11.I'd like to participate in similar programs. & 12 & - & - & $100 \%$ \\
\hline
\end{tabular}

It is obvious from the data presented in the table above that students' input concerning different dimensions of the program was positive. This is clearly indicated in the high ratio of agreement on 
all the statements of the evaluation sheet. However, the researcher increased the time of the program, simplified the instructions of the program to be clearer, and replaced some videos. After validating, piloting, and making use of the information collected to modify and improve it, the program became ready to be implemented in the main experiment of the research.

\section{Instrumentation}

The researcher used two different instruments to achieve the aims of the study; the researcher used a writing skill test as a main tool of the study.

\section{The Writing Test}

A writing skill test prepared by the researcher to measure the participants' achievement was used as a test-retest applied after the experiment.

\section{The General Aims of the Test}

The test aimed at measuring the effect of using the educational platform Edmodo on learning writing skills among third prep students.

\section{Description of the Test Items}

The test was divided into six parts. Each part consisted of one writing skill. The selected prescribed topic was related to students' needs in units ( $1 \& 2 \& 3 \& 4 \& 5 \& 6)$. Test items represented six types of writing skills: writing a letter, taking notes, writing a paragraph, writing an e-mail, writing a postcard, and writing an essay for the third-year prep stage in the first semester. They included information about the purpose of the test, the time permitted to complete the test, and the criteria on which scoring would be based. Moreover, the test was scored honestly.

\section{Scoring Technique of the Test}

Reviewing pertinent literature, the researcher prepared an analytical detailed rubric to evaluate student's performance in the EFL writing test. The researcher devised an analytical rubric to be used in scoring the writing skill test. The mark of the test out of 100 .

\section{The validity of the test}

\section{A. The Face (referee) validity}

To ensure the validity of the writing skill test, the researcher submitted it in its initial form to a jury of TFEL faculty members and supervisors Governmental Language Schools to decide on:

1. The clarity of the test instructions.

2. The suitability of the test items for assessing the content of the program.

3. The suitability of the test items for the thirdyear prep students' level.

4. The suitability of the scoring technique.

In general, the jury members appraised the test and its scoring rubric as being valid, clearly stated, and suitable for the purpose they were designed for and students' level of performance in English. Yet, they suggested some modifications; for example, specifying the test duration and restating the order of the items of the test. The items of the test were modified in the light of their recommendations.

\section{Piloting of the test}

In fact, in order to examine the suitability and appropriateness of the test in terms of time, difficulty and discrimination coefficient, the test was conducted (as a pilot test) on (12) students who had similar characteristics of the control and 
experimental groups. These (12) students studied at another school, El-Ballina Governmental Language School and were from the same cultural and environmental background. The researcher used the following equation to calculate the test time.

\section{Test time $=$}

$\frac{\text { The time needed for the 1st student }+ \text { the time needed for the last student }}{2}$

$$
=\frac{60+120}{2}=90 \text { minutes. }
$$

After applying the equation on the pilot study results, the researcher found that the time needed for the pre-test to be applied was 90 minutes.

\section{B. The Internal Consistency}

Internal consistency was calculated through the application of the test on a 12-student sample. This validity was calculated by using Pearson Formula. Table (4) shows the correlation coefficient of every item of the writing skill test within its domain was significant at levels (0.01) and (0.05).

Table (3) Establishing Internal Consistency of Writing Test Correlation coefficient of each item within its domains

\begin{tabular}{llll}
\hline Item & $\begin{array}{l}\text { Correlation coefficient of } \\
\text { the item with the whole } \\
\text { score of the dimension }\end{array}$ & Item & $\begin{array}{l}\text { Correlation coefficient of the item } \\
\text { with the whole score of the dimension }\end{array}$ \\
\hline 1 & $0.772^{* *}$ & 15 & $0.753^{* *}$ \\
2 & $0.843^{* *}$ & 16 & $0.717^{* *}$ \\
3 & $0.782^{* *}$ & 17 & $0.806^{* *}$ \\
4 & $0.692^{* *}$ & 18 & $0.875^{* *}$ \\
5 & $0.860^{* *}$ & 19 & $0.823^{* *}$ \\
6 & $0.802^{* *}$ & 20 & $0.831^{*}$ \\
7 & $0.823^{* *}$ & 21 & $0.679^{* *}$ \\
8 & $0.776^{* *}$ & 22 & $0.801^{* *}$ \\
9 & $0.735^{* *}$ & 23 & $0.775^{* *}$ \\
10 & $0.584^{*}$ & 24 & $0.814^{* *}$ \\
11 & $0.742^{* *}$ & 25 & $0.779^{* *}$ \\
12 & $0.821^{* *}$ & 26 & $0.642^{*}$ \\
13 & $0.713^{* *}$ & & \\
14 & $0.862^{* *}$ & & \\
\hline
\end{tabular}

$\mathrm{r}$ table value at $\mathrm{df}(10)$ and sig. level $(0.05)=0.532$

$\mathrm{r}$ table value at $\mathrm{df}(10)$ and sig. level $(0.01)=0.463$

It was noted from the previous table that the Correlation coefficient of the item with the whole score of the dimension was statistically significant. 
Table (4) 2. Correlation coefficient of each item within its sub-skill

\begin{tabular}{|c|c|c|c|}
\hline \multicolumn{2}{|c|}{ Organization of Ideas } & \multicolumn{2}{|c|}{ Quality of Content } \\
\hline Item & $\begin{array}{l}\text { Correlation coefficient of the item with } \\
\text { the whole score of the dimension. }\end{array}$ & Item & $\begin{array}{l}\text { Correlation coefficient of the item with } \\
\text { the whole score of the dimension. }\end{array}$ \\
\hline 1 & $0.820^{* *}$ & 1 & $0.682 * *$ \\
\hline 2 & $0.841^{* *}$ & 2 & $0.751 * *$ \\
\hline 3 & $0.780^{* *}$ & 3 & $0.801 * *$ \\
\hline 4 & $0.763^{* *}$ & 4 & $0.784 * *$ \\
\hline 5 & $0.822^{* *}$ & & \\
\hline \multicolumn{2}{|r|}{ Grammar } & \multicolumn{2}{|r|}{ Cohesion } \\
\hline Item & $\begin{array}{l}\text { Correlation coefficient of the item with } \\
\text { the whole score of the dimension. }\end{array}$ & Item & $\begin{array}{l}\text { Correlation coefficient of the item with } \\
\text { the whole score of the dimension. }\end{array}$ \\
\hline 1 & $0.764^{* *}$ & 1 & $0.782 * *$ \\
\hline 2 & $0.720 * *$ & 2 & $0.772 * *$ \\
\hline 3 & $0.732 * *$ & 3 & $0.692 * *$ \\
\hline \multirow[t]{3}{*}{4} & $0.840 * *$ & 4 & $0.744 * *$ \\
\hline & & 5 & $0.812 * *$ \\
\hline & Conventions & \multicolumn{2}{|r|}{ Word Choice } \\
\hline Item & $\begin{array}{l}\text { Correlation coefficient of the item with } \\
\text { the whole score of the dimension. }\end{array}$ & Item & $\begin{array}{l}\text { Correlation coefficient of the item with } \\
\text { the whole score of the dimension. }\end{array}$ \\
\hline 1 & $0.762 * *$ & 1 & $0.774 * *$ \\
\hline 2 & $0.803 * *$ & 2 & $0.816 * *$ \\
\hline \multirow[t]{4}{*}{3} & $0.824 * *$ & 3 & $0.772 * *$ \\
\hline & & 4 & $0.823 * *$ \\
\hline & & 5 & $0.815^{* *}$ \\
\hline & & 6 & $0.772 * *$ \\
\hline
\end{tabular}

$\mathrm{r}$ table value at $\mathrm{df}(10)$ and sig. level $(0.05)=0.532$

$r$ table value at $\mathrm{df}(10)$ and sig. level $(0.01)=0.661$

It was noted from the previous table that the Correlation coefficient of the item with the whole score of the dimension was statistically significant with its dimensions.

Table (5) 3. Correlation coefficient of the item with the whole score of the Test

\begin{tabular}{ll}
\hline Skill & $\begin{array}{l}\text { Correlation coefficient of the item with the } \\
\text { whole score of the Test }\end{array}$ \\
\hline Quality of content & $0.810^{* *}$ \\
Organization of the ideas & $0.783^{* *}$ \\
Coherence and cohesion & $0.803^{* *}$ \\
Grammar & $0.863^{* *}$ \\
Word choice & $0.840^{* *}$ \\
Conventions & $0.862^{* *}$ \\
\hline
\end{tabular}

$r$ table value at $\mathrm{df}(10)$ and sig. level $(0.05)=0.532$

$r$ table value at $\mathrm{df}(10)$ and sig. level $(0.01)=0.661$

It was noted from the previous table that the test with its different skills was characterized by its high internal consistency. 


\section{Reliability of the test}

The reliability of the test is intended to "give the same results if the test was used more than once under similar conditions" (Hossam El-Dein Muhammad Mazen 2012, 146), and the reliability of the test was verified by using the statistical program SPSS. To establish the reliability of the EFL writing skill, the Test-Retest method was used and estimated by IBM SPSS, Version 22.0. the 12 students of the pilot study performed the test twice. The time between the two administrations was two weeks.

\section{Test-Retest}

The reliability of the Test-retest was 0.986 . This result assured the program was effective.

\section{KR20 and Spearman \\ KR20}

The reliability of the test was measured by KR20 techniques. Table (6) shows (KR20) coefficients of the writing skill test.

Table (6) KR20 and coefficients of the writing skill test domains

\begin{tabular}{|ll|}
\hline Skill & $\begin{array}{l}\text { Cronbach's Alpha } \\
\text { coefficients }\end{array}$ \\
Quality of Content & 0.840 \\
Organization of Ideas & 0.851 \\
Cohesion & 0.782 \\
Grammar & 0.802 \\
Word Choice & 0.783 \\
Conventions & 0.814 \\
Total & $\mathbf{0 . 8 1 3}$ \\
\hline
\end{tabular}

It was clear from the previous table that the coefficient of Quality of content is (0.840), the coefficient of organization of ideas is $(0.851)$, the coefficient of coherence and cohesion is (0.782), the coefficient of grammar is (0.802), the coefficient of word choice is (0.783), the coefficient of conventions is $(0.814)$ and the total coefficient of writing skill test is (0.813). all the coefficients illustrate that the test has high reliability because its significance level was high.

\section{Spearman}

The reliability of the test was measured by the spearman technique. Using spearman to measure the reliability of the re-test. The researcher administrated the test at the first on 12 students from boys and girls then the researcher after two weeks administrates the test again.

Table (7) Spearman

\begin{tabular}{|ll|}
\hline Skill & Spearman coefficient \\
Quality of content & 0.842 \\
Organization of ideas & 0.850 \\
Cohesion and coherence & 0.791 \\
Grammar & 0.802 \\
Word choice & 0.781 \\
Conventions & 0.814 \\
Total & $\mathbf{0 . 8 1 3}$ \\
\hline
\end{tabular}

It is clear from the previous table that the test with its skills has a high correlation.

\section{Inter-Rater Reliability}

To determine the test reliability of the study by inter-rater method, the test of writing was written by the participants in the pilot study were scored by the two independent raters. Before scoring, these raters were scoring in the use of the scoring technique.

Table (8) Correlation coefficient between the two Raters

\begin{tabular}{lll} 
& \multicolumn{2}{l}{ Correlation } \\
\cline { 2 - 3 } Rater 1 & $0.85^{* *}$ & 1 \\
Rater 2 & 1 & $0.85^{* *}$ \\
\hline
\end{tabular}




\section{Procedures of the Study}

To conclude the experiment of this research, the procedures below were followed:

1. Reviewing literature and previous studies related to connectivism and the use of the Edmodo and their effect on the writing skills. Also, the researcher reviewed previous studies related to the use of Edmodo in teaching and learning writing. This is to get benefit from their samples, tools, methodology, results, and recommendations.

2. Preparing a theoretical framework by reviewing the literature concerned.

3. Preparing a writing rubric to the preparatory school students, submitting it to the jury members of specialists in curricula and methods of teaching in English language and verify from its validity.

4. Designing an educational scenario for a program based on connectivism through using the educational platform Edmodo.

5. Submitting the educational scenario to jury members of methods of teaching technology.

6. Modifying the educational scenario in light of the jury's opinions and reaching the final form.

7. Preparing a preliminary image for the program based on connectivism through using educational platform Edmodo and presented to the jury members to verify the validity of the program and its applicability.

8. Framing the program in its final form after the proposed adjustments of the jury members.

9. Evaluate and publish the program.
10. Preparing the teacher's Edmodo and student's Edmodo.

11. Obtaining permission from the Assuit University, the Ministry of Education, and Sohag Directorate to help the researcher conduct the study.

12. Conducting a pilot study to measure the test and the scale suitability to the study on October $14^{\text {th }}, 2019$.

13. Making sure that both groups were equivalent and conducting the experiment.

14. Checking the validity and reliability of the test.

15. Choosing the sample of the study that included the experimental group and the control one.

16. Implementing the experiment using Edmodo according to the plan on the experimental group, while the control one was taught by the traditional method on November $4^{\text {th }}$, 2019.

17. On December 19, 2020, the researcher applying the re-test on the sample of the study and computing the results.

18. Analyzing the collected data and giving interpretations.

19. Presenting the suggestions and giving recommendations in the light of study results.

\section{Results \& Discussion}

\section{Firstly, Testing the Hypothesis}

\section{The Question of the Study}

The question of the research was stated as follows: 
"What's the effect of a suggested connectivism based- program through using Edmodo for

developing third-year prep students' writing skills?"

To answer the question, it was hypothesized that:

Table (9) Mann Whitney Independent Sample Test Results of the Differences between the Experimental and the Control Groups in the Writing Post-Test.

\begin{tabular}{|c|c|c|c|c|c|c|c|c|c|}
\hline Sub Skills & $\mathrm{N}$ & the group & Mean & $\begin{array}{l}\text { Std. } \\
\text { Deviation }\end{array}$ & $\begin{array}{l}\text { Mean } \\
\text { Rank }\end{array}$ & $\begin{array}{l}\text { Total } \\
\text { ranks }\end{array}$ & Df & Z-value & Sig \\
\hline \multirow{2}{*}{ 1.Quality of Content } & 22 & experimental & 28.36 & 2.015 & 33.50 & 737 & \multirow{2}{*}{42} & \multirow{2}{*}{-5.768} & \multirow{2}{*}{0.001} \\
\hline & 22 & Control & 8.89 & 1.532 & 11.50 & 253 & & & \\
\hline \multirow{2}{*}{$\begin{array}{l}\text { 2.Organization of } \\
\text { Ideas }\end{array}$} & 22 & experimental & 19.31 & 0.893 & 34.50 & 759 & \multirow{2}{*}{42} & \multirow{2}{*}{-5.874} & \multirow{2}{*}{0.003} \\
\hline & 22 & Control & 8.95 & 1.703 & 12.00 & 276 & & & \\
\hline \multirow{2}{*}{ 3.Cohesion } & 22 & experimental & 14.36 & 0.847 & 35.41 & 751 & \multirow{2}{*}{42} & \multirow{2}{*}{-5.210} & \multirow{2}{*}{0.018} \\
\hline & 22 & Control & 7.90 & 1.659 & 13.20 & 266 & & & \\
\hline \multirow{2}{*}{ 4-Grammar } & 22 & experimental & 14.72 & 1.214 & 33.52 & 771 & \multirow{2}{*}{42} & \multirow{2}{*}{-5.661} & \multirow{2}{*}{0.001} \\
\hline & 22 & Control & 7.45 & 0.455 & 12.00 & 264 & & & \\
\hline \multirow{2}{*}{ 5.Word Choice } & 22 & experimental & 9.00 & 1.191 & 33.16 & 729 & \multirow{2}{*}{42} & \multirow{2}{*}{-5.666} & \multirow{2}{*}{0.022} \\
\hline & 22 & Control & 6.09 & 0.898 & 11.84 & 260 & & & \\
\hline \multirow{2}{*}{ 6.conventions } & 22 & experimental & 8.72 & 1.608 & 33.72 & 742 & \multirow{2}{*}{42} & \multirow{2}{*}{-5.979} & \multirow{2}{*}{0.00} \\
\hline & 22 & Control & 5.27 & 0.935 & 11.60 & 265 & & & \\
\hline \multirow{2}{*}{ Total Score } & 22 & experimental & 94.17 & 5.65 & 33.61 & 726 & \multirow{2}{*}{42} & \multirow{2}{*}{-5.687} & \multirow{2}{*}{0.004} \\
\hline & 22 & Control & 43.86 & 3.173 & 11.52 & 249 & & & \\
\hline
\end{tabular}

In the table (9) the results show that the (z) calculated value is excellent in all the test writing skills and in the total test score. This means that there are statistically significant differences at (0.05) level between the experimental group and the control group in favor of the experimental group. There is also a significant difference in favor of the experimental group, between the mean ranks of both groups. The mean rank of the control group is (11.52) compared to the total score of the test while the mean of the experimental group is (33.61). This means that using the Edmodo educational platform Edmodo in the English writing class is effective in developing students' writing skills.

Also, from the previous Table (9) it is clear that the $\mathrm{z}$ values of the test and sub-skills as a whole were $(-5.768,-5.874,-5.210,-5.661,-5.666$, $5.979,-5.6870)$ respectively and the corresponding probability values of $(0.001,0.003$, $0.018,0.001,0.022,0.00,0.004)$ and the level of significance at $(\leq 0.05)$.

The mean rank for each skill and total as a whole (33.50, 34.50, 35.41, 33.52, 33.16, 33.72, 33.61), respectively, were statistically significant differences between the average ranks of students 
between the experimental and control groups $(264,276,266,264,260,265,249)$.

\section{The Effect Size of Experimental Group}

The effect size depends on the type of statistical test; the corresponding effect size for each statistical test is calculated using the appropriate equation.

Table (10) The Effect Size of Edmodo on the Experimental group and Control group in the administration of the Writing Skill Test.

\begin{tabular}{lllll}
\hline Skills & $\begin{array}{l}\text { Mean of Experimental } \\
\text { group }\end{array}$ & $\begin{array}{l}\text { Mean of Control } \\
\text { group }\end{array}$ & $\begin{array}{l}\text { The effect } \\
\text { size }\end{array}$ & $\begin{array}{l}\text { Effect } \\
\text { Volume }\end{array}$ \\
\hline 1.Quality of Content & 28.36 & 8.89 & 0.82 & Large \\
2.Organization of Ideas & 19.31 & 8.95 & 0.83 & Large \\
3.Coherence and Cohesion & 14.36 & 7.90 & 0.88 & Large \\
4.Grammar & 14.72 & 7.45 & 0.84 & Large \\
5.Word Choice & 9.00 & 6.09 & 0.86 & Large \\
6.Conventions & 8.72 & 5.27 & 0.85 & Large \\
Total Score & 94.17 & 43.86 & 0.85 & Large \\
\hline
\end{tabular}

For each skill, there is large effect size and the total score for each skill it is $85 \%$. Implementing the effect size equation, the researcher found that the effect size of the writing skills is content quality is $81 \%$, organization of ideas is $85 \%$, coherence and cohesion is $83 \%$, Grammar is $88 \%$, word choice is $88 \%$, and conventions is $84 \%$. The question investigated would develop the EFL writing skills of the third-year prep students through the educational platform Edmodo. This online course was found to be effective and helpful in developing writing skills. The findings of the in-depth study of scores of the students also showed a major increase in the writing abilities of the EFL. Checking the students' answers to the Test questions and their answers in the discussion showed that their writing skills developed significantly. The finding of the study hypothesis, which tested the statistically significant difference between the mean scores of the control group and those of the experimental one for learning English writing, showed that there were statistically significant difference between the experimental group and the control group in favor of the experimental group at (0.05) level. Furthermore, these findings indicated that the $(\mathrm{t})$ computed value was larger than the (t) table value in the Test. This meant that there was statistically significant difference between the experimental group and the control one to the total Test marks in favor of the experimental group. There was also a significant difference between the means of both groups in favor of the experimental group as the mean of the experimental group was (94.17), whereas that of the control group was (43.86). Also, the researcher found that the effect size was significantly large.

\section{Conclusion}

The present study examines the effect of the educational platform Edmodo on developing some writing skills. The study was used to 
improve the quality of content, organization of ideas, grammar. Cohesion and conventions. The study aimed to practice writing a letter, paragraph, note, postcard, e-mails and postcard to enhance the writing performance and behavior of third-year prep students. Continued research and replication is necessary for educational platform Edmodo to develop writing skills and the other different skills at English as a foreign language. Further research is needed to explore educational platform Edmodo training affects the writing quality and performance with third-year prep students at the governmental language school.

Based on the previously mentioned, the following conclusions can be mentioned:

- Third-year prep students' low level of writing is due to the traditional methods and shortage of time prevailing in language school which could be represented in just lecturing.

- Researchers conducted many studies that aimed at developing writing skills using different approaches.

- Research using educational platform Edmodo at other subjects and at English language skills.

\section{References}

Alfian A. 2013. Micro-blogging assisted learning strategy in teaching writing (A Classroom Action Research at the Tenth Year Students of SMA Al-Azhar BSD in 2011/2012 Academic Year). Unpublished master thesis, Faculty of Tarbiya and Teacher Training, State Islamic University Syarif Hidayatullah Jakarta, Indonesia.
Abadi B. B. S., Ahmadi S. D. \& Mehrdad A. G., 2015. The effect of Edmodo on EFL learners "writing performance. International Journal of Educational Investigations, 2, pp. 88-97.

Adas D., Bakir A., 2013. Writing difficulties and new solutions: Blended learning as an approach to improve writing abilities. International journal of humanities and social science, 3(9): 254-266.

Al-Okaily R., 2013. Mobile learning and BYOD: implementations in an Intensive English Program. Learning and Teaching in Higher Education: Gulf Perspectives, 10(2): 1-7.

Anbe G., 2013. Using Edmodo to Incorporate WICOR Strategies in the AVID Classroom. Unpublished Master dissertation, University of Hawai $i$ at Manoa, United States of America.

Arroyo G., 2011. On-Line Social Networks: Innovative Ways towards the Boost of Collaborative Language Learning. ICT for Language Learning ( $4^{\text {th }}$ ed.). In International Conference "ICT For Language Learning", Pixel.

Carolan F. \& Kyppö A., 2015. Teaching process writing in an online environment. Voices of pedagogical development-Expanding, enhancing, and exploring higher education language learning, 13-30.

Cole M., 2012. Looking to the future: A Delphi study forecasting the use of social technology tools and applications in $\mathrm{PK}-12$ teaching and learning over the next five years. Published doctoral dissertation, ProQuest journal, university of Saint Louis, United States. 
Donmus V., 2010. The use of social networks in educational computer-game based foreign language learning. Procedia-Social and Behavioral Sciences, 9: 1497-1503.

Dowling S., 2011. Web-based learning-Moving from learning islands to learning environments. TESLEJ, 15(2): 1-27.

Enriquez M. A. S., 2014. Students' Perceptions on the Effectiveness of the Use of Edmodo as a Supplementary Tool for Learning. In DLSU Research Congress, De La Salle University, Manila, Philippines.

Evans, C. (2008). The effectiveness of m-learning in the form of podcast revision lectures in higher education. Computers \& education, 50(2), 491498.

Gardner M., 2013. Social media and peer review: Edmodo in the composition classroom. Dissertations, Theses and Capstone Projects.

Gushiken B., 2013. Integrating Edmodo into a High School Service Club: To Promote Interactive Online Communication. Unpublished Master dissertation, University of Hawai $i$ at Manoa, United States of America.

Hariri R. O. \& Bahanshal D. A., 2015. Maximizing L2 interaction through using Edmodo in Saudi EFL classrooms. International Journal of Linguistics, Literature and Culture, 2(4): 48- 60.

Heng, Mdm. (n, d) Edmodo - A communication tool for parents and a collaborative learning platform for pupils. Available online at: www.medialiteracycouncil.sg.
Hourdequin P., 2014. Edmodo: A simple tool for blended learning. The Language Teacher, Issue 38. Japan Association for Language Teaching. 38(1): 34-35.

Karyawati A., 2014. A descriptive study on the use of Edmodo website for English teaching and learning process in Salatiga State Institute for Islamic studies (Unpublished Thesis). Salatiga: Salatiga State Institute for Islamic Studies.

Keneth A., 2010. Good writers are made, not born. Available online at:

http://ezinearticles.com/?Good-Writers-Are-

Made,Not- Born\&id=5207882.

Lara V. D., 2013. The improvement of writing based on a genre approach through the use of an e-learning platform (Unpublished Thesis). University of Veracruz, Veracruz.

Looi C. Y. \& Yusop F. D., 2011. Potential use of social networking tool to assist reading comprehension: Implications for practice and future research. Journal Pendidikan.

Newby T. J., Stepich D.A., Lehman, J. D. \& Russel J. D., 2006. Educational technology for teaching and learning ( $3^{\text {rd }}$ ed.). Upper Saddle River, New Jersaye: Merril/Prentice hall.

Ma'azi H. \& Janfeshan K., 2018. The effect of Edmodo social learning network on Iranian EFL learners writing skill. Cogent Education, 5(1).

Mills K., \& Chandra V., 2011. Micro-blogging as a literacy practice for educational communities. Journal of Adolescent \& Adult Literacy, 55(1): $35-45$. 
Monalisa M. \& Ardi H., 2013. Using "Edmodo" educational social network in teaching English for high school students. Journal of English Language Teaching, 2(1): 220-225.

Msanjila Y. P., 2005. Problems of writing in Kiswahili: A case study of Kigurunyembe and Morogoro secondary schools in Tanzania. Nordic Journal of African Studies 14(1): 15-25.

Letwinsky K. M., 2012. Teacher self-efficacy and the use of the Internet to cultivate mathematics literacy. ProQuest LLC.

Pop A., 2013. Edmodo e-portfolios in EFL-A case study. In 8th International conference on Virtual Learning, Vol. (1), p. 25-26.

Scott S. M., 2012. Go ahead.. be social: Using social media to enhance the twenty-first century classroom. Distance Learning, 9(2): 54.

Seow A., 2002. The writing process and process writing. In Richards, J. And Renandya, W. (Eds.) Methodology in Language Teaching: An Anthology of Current Practice. United Kingdom: Cambridge University Press. p.p. 315-320.

Shams-Abadi, B. B., Ahmadi, S. D., \& Mehrdad, A. G. (2015). The effect of Edmodo on EFL learners' writing performance. International Journal of Educational Investigations, 2(2): 8897.

Shockney R. 2013. Measuring effectiveness of a social networking site in a middle school. California State University San Marcos.
Spelkova, I. \& Hurst, N. (n.d) Teachers' Attitudes to Skills and the Writing Process in Latvia and Portugal. Unpublished M.A Thesis. Rezekne State Gymnasium, Latvia.

Spiotta L., 2013. The role of technology in a sixthgrade classroom. Journal of Education and Human Development Master's Theses, p.187.

Thibaut P., 2015. Social network sites with learning purposes: Exploring new spaces for literacy and learning in the primary classroom. Australian Journal of Language and Literacy, 38(2): 83.

Thongmak M., 2013. Social network system in classroom. Journal of E-Learning and Higher Education, Vol. 2013 (2013), Article ID 657749, DOI: $10.5171 / 2013.657749$.

Wallace A., 2013. Social learning platforms and the flipped classroom. In e-Learning and eTechnologies in Education (ICEEE). International journal of information and education technology 4(4): 293-296.

Ware P. D. \& Warschauer M., 2006. Electronic feedback and second language writing. Feedback in second language writing: Contexts and issues, 105-122.

Wendt J., 2013. The effect of online collaborative learning on middle school student science literacy and sense of community. Unpublished Doctoral Dissertation, University of Liberty, Lynchburg. 